\title{
Potential of Cowpea Variety Mixtures to Increase Yield Stability in Subsistence Agriculture: Preliminary Results
}

\author{
Joshua S. Okonya ${ }^{1,2}$ and Brigitte L. Maass ${ }^{1,3}$ \\ ${ }^{1}$ Institute of Agronomy in the Tropics, Georg-August-Universität, Grisebachstr. 6, 37077 Göttingen, Germany \\ ${ }^{2}$ Global Program of Integrated Crop and Systems Research, International Potato Center (CIP), P.O. Box 22274, Kampala, Uganda \\ ${ }^{3}$ Tropical Forages Program, International Center for Tropical Agriculture (CIAT), P.O. Box 823-00621, Nairobi, Kenya
}

Correspondence should be addressed to Joshua S. Okonya; j.okonya@cgiar.org

Received 7 May 2013; Revised 3 October 2013; Accepted 7 November 2013; Published 23 January 2014

Academic Editor: Othmane Merah

Copyright (C) 2014 J. S. Okonya and B. L. Maass. This is an open access article distributed under the Creative Commons Attribution License, which permits unrestricted use, distribution, and reproduction in any medium, provided the original work is properly cited.

\begin{abstract}
Cowpea Vigna unguiculata (L.) Walp. is an important leafy vegetable and grain legume in Uganda. Unlike in commercial agriculture, where variety mixtures are known to give higher and more stable yields, the performance of cowpea variety mixtures in subsistence agriculture is little known. Mixtures containing up to four cowpea varieties were subjected to all possible 2-way, 3-way, and 4-way combinations. These cowpea varieties and mixtures were grown at three locations in Soroti and Kumi districts in order to assess the relative mixture effect, defined as: Mixture effect $(\%)=($ mixture yield - pure line component average)/pure line component average $\times 100$. Yield data was subjected to one-way ANOVA using the GLM procedure of SYSTAT. PLABSTAT was used to generate ecovalence $\left(W_{i}\right)$ values as a measure of stability with low ecovalence values indicating higher stability. The total cowpea dry matter $(\mathrm{DM})$ yield was in the range of $3.7-6.7 \mathrm{~g} / \mathrm{m}^{2}$ (leaf) and $12.1-36.7 \mathrm{~g} / \mathrm{m}^{2}$ (grain), respectively. Mixture effects were between $-9.3-14.0 \%$ (leaf) and $-30.3-21.9 \%$ (grain). Yield stability spanned $W_{i}=0.06-5.30$ (leaf) and $W_{i}=4.45-894.84$ (grain). The results suggested that yields of cowpea variety mixtures grown in marginal environments were more stable than of single varieties but not all mixtures yielded more than single varieties.
\end{abstract}

\section{Introduction}

Cowpea Vigna unguiculata (L.) Walp. is one of the top four traditional leafy vegetables in Uganda grown for both its grains and leaves $[1,2]$. Cowpea forms an integral part of the cropping systems in subsistence agriculture where it is usually grown in intercrop with maize Zea mays L., sorghum Sorghum bicolor (L.) Moench, cassava Manihot esculenta Crantz, or mung bean Vigna radiate (L.) R. Wilczek especially in the Eastern and Northern districts, which produce $90 \%$ of the cowpea in Uganda [3, 4]. Lack of improved varieties, low soil fertility, and insect pests are among the most important constraints to cowpea production in Uganda leading to low grain yields of $200-400 \mathrm{~kg} / \mathrm{ha}$ [5-7], while leaf yield levels had never been assessed.

Through complementation like increased nutrient availability, better resource exploitation, compensation for injured or weak varieties, and restriction of disease for specialized pathogens, variety mixtures have been shown to stabilize and enhance yields in farming systems, where farmers lack the means to minimise environmental variation through management practices like pesticide and irrigation use $[8,9]$. Although the effect of variety mixtures on leaf and grain yields of cowpea in subsistence agriculture is not known, a number of studies with cereals in Europe and USA show certain yield advantages [10].

The mean yields and volume weights of five early maturing oat cultivars on average were higher and more stable across environments in variety mixtures than in individual varieties [11]. The development of scald and net blotch infections in winter barley Hordeum vulgare L. were reduced by $12 \%$ in mixtures compared to pure stands [12]. Yield variability of hard red winter wheat Triticum aestivum $\mathrm{L}$. was less for mixtures than for individual varieties, and mixtures had a yield advantage of $57 \mathrm{~kg} / \mathrm{ha}$ [9]. Cowger and Weisz [13] report that soft red wheat mixtures significantly out-yielded 
TABLE 1: Cowpea varieties used in the study of variety mixtures in Soroti and Kumi districts of Uganda during the first cropping season of 2008.

\begin{tabular}{lccr}
\hline ID & Variety & Status & Growth habit \\
\hline A & UG-CP-9 (KOL 42) & Experimental line & Indeterminate \\
B & Dakawa & Cultivar & Determinate \\
C & Ex-Iseke & Cultivar & Determinate \\
D & IT 93K-2045-29 & Experimental line & Determinate \\
D $^{*}$ & ILRI 15742 & Research material & Determinate \\
E & Icirikukwai & Landrace & Indeterminate \\
F & Ebelat & Landrace & Determinate \\
\hline
\end{tabular}

$\mathrm{D}^{*}$ was used in place of $\mathrm{D}$ in the trial at Kikota village due to insufficient seed available of $\mathrm{D}$.

the means of their components across two environments with an overall advantage of $130 \mathrm{~kg} / \mathrm{ha}$ and were more stable. Grain yields of two of four cowpea mixtures tested were more stable than those of their pure lines [14]. Blade et al. [15] observe that the more stable cowpea lines tended to be low-yielding in both low- and high-yielding environments while the least stable lines out-yielded other lines in all except the poor environments.

In industrial agricultural systems, successful utilization of variety mixtures by farmers is reported for winter wheat in Russia, wheat and barley in the UK [8], spring barley in East Germany and Denmark $[8,16]$, wheat (KSLM3, a mixture of six components) in India [17], and oats Avena sativa L. and barley in Ontario, Canada [8]. In Scotland, mixtures of three wheat varieties (Virtue, Mardler, and Husler) set the world record wheat yield of $13.99 \mathrm{t} / \mathrm{ha}$ in 1981 [18]. Current successful use of intracrop diversification can be seen for instance in Washington state, USA, where 688 ha were planted to a soft white club winter wheat multiline "Rely" in 2007 [19]. Winter hardy wheat varieties are grown by farmers in Oregon state, USA, together with droughtresistant varieties to reduce losses due to cold or drought [16].

Based on their comprehensive reviews of multiline cultivars and variety mixtures, Wolfe [8] and Lenné and Smithson [10] point out that variety mixtures are cultivated to a greater extent than is usually imagined, especially in traditional agriculture. Examples of variety mixture use include rice Oryza sativa L. mixtures in the Philippines, Indonesia, and Sierra Leon with two to five components that match the same maturity periods and yield. In their review, Lenné and Smithson [10], however, report that up to 44-90 rice varieties are grown together in the same garden by farmers in these regions. Twenty-five to 35 potato Solanum tuberosum L. varieties are usually grown by subsistence farmers in the Andes, while 20 sweet potato Ipomoea batatas (L.) Lam. varieties may be grown in the same garden in the highlands of Papua New Guinea [10]. In Africa, south Asia, and the Pacific, as many as 38 different varieties of yam Dioscorea spp. may be planted together [10]. Common beans Phaseolus vulgaris L. in East Africa and in the great lakes region are usually grown in mixtures of two to 30 varieties, which may differ even in color, size, and shape [10, 20]. East African Highland cooking bananas Musa spp., AAA group and sweet potato in Uganda (Okonya, personal observation), cassava in Peru, and barley in Syria are often grown as mixtures [10].
Although variety mixtures have shown to give higher and stable yields across environments in commercial agriculture, especially, with cereals [16], the performance of cowpea variety mixtures in subsistence agriculture is little known. This may depend on the fact that, in smallholder subsistence agriculture, landraces of unknown genetic makeup predominate. No published results on leafy cowpea could be traced for Uganda. Neither was there any known study that focused on either leaf or grain yields of cowpea mixtures in Uganda. The specific objectives of this study were to (i) determine whether leaf and grain yields of mixtures are higher than those of individual cowpea varieties; (ii) to compare both leaf and grain yield stability of mixtures and individual cowpea varieties across three locations in Eastern Uganda; and (iii) to find out whether yield or stability of a cowpea variety mixture increases with increasing number of components.

\section{Materials and Methods}

2.1. Plant Material. Seven dual purpose cowpea varieties differing in morphology and growth habit were used for this study (Table 1). These different germplasm materials are all called "variety" throughout this paper, despite their status, and are each assigned a letter for identification (ID). Cowpea varieties were intercropped with maize cv. Situka 1, which is a drought-tolerant and low-nitrogen requiring, open-pollinated synthetic variety released in 2001 by Selian Agricultural Research Institute (SARI), Tanzania. Seeds of cowpea varieties A, B, C, and D were provided by the World Vegetable Center's Regional Center for Africa (AVRDCRCA), Arusha, Tanzania. Seeds of cowpea varieties E and F were bought from the local market at Serere, Soroti, Uganda.

2.2. Experimental Sites. Yield evaluations were conducted at three locations in Soroti and Kumi districts. Trial 1 was conducted at the National Semi Arid Resources Research Institute (NaSARRI), Serere ( $033^{\circ} 26^{\prime} 48.0^{\prime \prime}$ E longitude, $01^{\circ} 32^{\prime} 22.6^{\prime \prime} \mathrm{N}$ latitude and an elevation of $1140 \mathrm{~m}$ above sea level). The second trial was carried out at a farmer's field in Kikota village $\left(033^{\circ} 28^{\prime} 22.9^{\prime \prime}\right.$ E longitude, $01^{\circ} 32^{\prime} 09.6^{\prime \prime} \mathrm{N}$ latitude and an elevation of $1077 \mathrm{~m}$ asl.), about $3 \mathrm{~km}$ East of NaSARRI. The third trial was conducted on farm at Kogili village $\left(033^{\circ} 27^{\prime} 01.1^{\prime \prime} \mathrm{E}\right.$ longitude, $01^{\circ} 32^{\prime} 22.7^{\prime \prime} \mathrm{N}$ latitude and an elevation of $1119 \mathrm{~m}$ asl.), about $65 \mathrm{~km}$ South East of NaSARRI. The soils are classified as ferralitic (sandy loams to sandy clay 
TABLE 2: Soil characteristics at the three trial sites in Soroti and Kumi districts, Uganda.

\begin{tabular}{lcccc}
\hline Soil parameter & Unit & & \multicolumn{2}{c}{ Trial site } \\
pH & & NaSARRI, Serere, Soroti district & Kikota village, Soroti district & Kogili village, Kumi district \\
\hline Sand & $\%$ & 47 & 6.0 & 5.9 \\
Clay & $\%$ & 20 & 60 & 68 \\
Silt & $\%$ & 33 & 18 & 25 \\
Organic matter & $\%$ & 2.38 & 22 & 7 \\
Nitrogen & $\%$ & 0.18 & 3.26 & 1.59 \\
Phosphorous (Bray 1$)$ & $\mathrm{mg} / \mathrm{kg}$ & 2.45 & 0.11 & 0.09 \\
Calcium & $\mathrm{cmoles} / \mathrm{kg}$ & 5.4 & 5.72 & 2.85 \\
Magnesium & $\mathrm{cmoles} / \mathrm{kg}$ & 1.19 & 5.7 & 3.0 \\
Potassium & $\mathrm{cmoles} / \mathrm{kg}$ & 0.29 & 1.84 & 1.33 \\
Sodium & $\mathrm{cmoles} / \mathrm{kg}$ & 0.07 & 0.37 & 0.34 \\
Copper & $\mathrm{mg} / \mathrm{kg}$ & 2.84 & 0.08 & 0.07 \\
Iron & $\mathrm{mg} / \mathrm{kg}$ & 211.7 & 5.04 & 2.10 \\
Zinc & $\mathrm{mg} / \mathrm{kg}$ & 1.20 & 221.1 & 264.3 \\
Manganese & $\mathrm{mg} / \mathrm{kg}$ & 37.2 & 1.74 & 1.74 \\
\hline
\end{tabular}

Source: soil, water, and plant analytical laboratory, Department of Soil Science, Makerere University, Kampala, Uganda.

loams) with a yellowish to red colour [21]; they are slightly to moderately acidic with low to deficient soil fertility (Table 2).

Soroti and Kumi districts are in a semiarid agroecological zone with two rainy seasons. The first season occurs between March and July and the second season is between September and November. The average annual rainfall in this region varies from 800 to $1200 \mathrm{~mm}$. Kikota village is presumed to have experienced weather conditions similar to those at NaSARRI $(153.4 \mathrm{~mm}$ mean monthly rainfall, $18.7^{\circ} \mathrm{C}$ mean $T_{\min }$, and $28.8^{\circ} \mathrm{C}$ mean $T_{\max }$ ). The weather station at Soroti Flying School in Soroti district is taken to be representative of the weather conditions at Kogili village (107.3 mm mean monthly rainfall, $18.3^{\circ} \mathrm{C}$ mean $T_{\text {min }}$, and $29.5^{\circ} \mathrm{C}$ mean $\left.T_{\max }\right)$ as it is the only nearest meteorological station at about $50 \mathrm{~km}$ from Kogili village.

2.3. Experimental Design and Treatments. The trials were laid out in a completely randomized block design with three replications for each treatment. Four cowpea varieties (A, $B, C$, and $D)$ were subjected to all possible 2-way $(A+B$, $\mathrm{A}+\mathrm{C}, \mathrm{A}+\mathrm{D}, \mathrm{B}+\mathrm{C}, \mathrm{B}+\mathrm{D}$, and $\mathrm{C}+\mathrm{D})$, 3-way $(\mathrm{A}+\mathrm{B}+\mathrm{C}$, $\mathrm{A}+\mathrm{B}+\mathrm{D}, \mathrm{A}+\mathrm{C}+\mathrm{D}$, and $\mathrm{B}+\mathrm{C}+\mathrm{D})$, and 4-way $(\mathrm{A}+$ $\mathrm{B}+\mathrm{C}+\mathrm{D})$ combinations. Two landraces ( $\mathrm{E}$ and $\mathrm{F})$ were included as local checks. Seeds of each variety were planted as pure lines (control for mixture treatments) and as blends in a systematically alternating manner. Data was collected from the two inner rows of cowpea; one row of cowpea was for leafharvesting, while the other row was left unharvested.

2.4. Crop Husbandry. The trial site at NaSARRI, Serere, was ploughed and disked using a tractor, while the trial sites at Kikota and Kogili villages were ploughed using oxen. Cowpea was intercropped with maize, which is a common practice in subsistence agriculture. Spacing for maize was
$75 \times 60 \mathrm{~cm}$ while that of cowpea was $75 \times 20 \mathrm{~cm}$. Five rows of maize and four rows of cowpea were interplanted. Each plot measured $3 \times 6 \mathrm{~m}$ spaced $1 \mathrm{~m}$ between treatments and $1.5 \mathrm{~m}$ between replicates. Three seeds of both cowpea and maize were planted per hill. Cowpea was planted on 13/05/08 at Serere, 15/05/08 at Kikota, and 20/05/08 at Kogili, two weeks after maize was planted. After two weeks, maize was thinned to two plants per hill, while cowpea was thinned to one plant per hill. Cowpea was sprayed four times with dimethioate at a rate of $2500 \mathrm{~mL} / \mathrm{ha}$ at 2-3-week intervals to control insect pests at all the three sites. Weeds were manually removed using a hand hoe whenever it was needed. Neither irrigation nor fertilizers were applied in any of the three trials.

2.5. Cowpea Leaf and Grain Yields. The first leaf-harvest was at four weeks after planting cowpea. Leaf-harvest continued every two weeks until flowering. Three leaf-harvests were made at NaSARRI, Serere, and Kikota village, while four leafharvests were possible at Kogili village. Only fully opened trifoliolate, tender leaves suitable for human consumption were hand-picked and their fresh weight was taken. After harvest, leaf samples were sun-dried in net bags $(320 \times$ $440 \mathrm{~mm}$ ) for 1-2 weeks to obtain the dry weight. At maturity, pods were hand-harvested and counted per plant. At the end of the trial, pods were sun-dried in net bags $(430 \times 550 \mathrm{~mm})$ for about one week and hand-shelled, and the seeds were weighed to assess grain yield.

2.6. Data Analysis. Cowpea leaf DM yields from three or four harvests at each location were summed up to obtain total leaf DM yield per plot at each site from which yield per square meter was calculated. Yield data for cowpea leaf and grain from three replicated plots of cowpea in each environment was subjected to one-way ANOVA using the GLM procedure 
TABLE 3: Stability (expressed by ecovalence) of grain yield of individual cowpea varieties and their possible mixtures grown at NaSARRI, Serere, Kikota, and Kogili villages in Uganda during the first cropping season of 2008.

\begin{tabular}{|c|c|c|c|c|c|c|}
\hline Treatment & $\begin{array}{c}\text { Mean leaf } \\
\text { DM yield }\left(\mathrm{g} / \mathrm{m}^{2}\right)\end{array}$ & $\begin{array}{c}\text { Ecovalence value } \\
\qquad W_{i}\end{array}$ & $\begin{array}{c}\text { Mean grain } \\
\text { yield_H }\left(\mathrm{g} / \mathrm{m}^{2}\right)\end{array}$ & $\begin{array}{c}\text { Ecovalence value } \\
\qquad W_{i}\end{array}$ & $\begin{array}{c}\text { Mean grain } \\
\text { yield_NH }\left(\mathrm{g} / \mathrm{m}^{2}\right)\end{array}$ & $\begin{array}{c}\text { Ecovalence value } \\
W_{i}\end{array}$ \\
\hline A & 3.7 & 0.67 & 34.7 & 894.84 & 28.9 & 69.90 \\
\hline B & 6.3 & 2.15 & 28.2 & 52.38 & 36.7 & 104.82 \\
\hline $\mathrm{C}$ & 6.7 & 0.77 & 17.9 & 12.50 & 25.5 & 84.25 \\
\hline $\mathrm{D}$ & 4.6 & 5.03 & 12.1 & 65.64 & 21.0 & 44.16 \\
\hline Mean & 5.3 & 2.16 & 23.3 & 256.34 & 28.0 & 75.78 \\
\hline $\mathrm{E}$ & 2.4 & 1.01 & 16.5 & 28.09 & 18.8 & 28.02 \\
\hline $\mathrm{F}$ & 4.1 & 0.28 & 20.4 & 78.38 & 16.4 & 33.38 \\
\hline Mean & 3.3 & 0.65 & 18.5 & 53.24 & 17.6 & 30.70 \\
\hline$A+B$ & 4.6 & 0.11 & 14.7 & 63.14 & 25.4 & 7.18 \\
\hline$A+C$ & 5.5 & 0.74 & 23.3 & 5.71 & 22.8 & 35.18 \\
\hline$A+D$ & 3.9 & 2.35 & 12.3 & 102.03 & 18.8 & 51.22 \\
\hline$B+C$ & 6.7 & 1.15 & 19.7 & 11.84 & 30.3 & 46.65 \\
\hline$B+D$ & 5.9 & 0.06 & 21.5 & 4.45 & 23.4 & 66.29 \\
\hline$C+D$ & 6.6 & 1.44 & 21.0 & 14.72 & 25.2 & 26.33 \\
\hline Mean & 5.5 & 0.98 & 18.8 & 33.65 & 24.3 & 38.81 \\
\hline$A+B+C$ & 5.6 & 0.26 & 16.7 & 18.64 & 27.7 & 30.83 \\
\hline$A+B+D$ & 5.2 & 0.36 & 25.1 & 42.48 & 29.1 & 9.58 \\
\hline$A+C+D$ & 4.7 & 0.44 & 17.1 & 173.03 & 23.7 & 37.60 \\
\hline$B+C+D$ & 5.7 & 1.55 & 22.3 & 4.87 & 23.0 & 125.22 \\
\hline Mean & 5.3 & 0.65 & 20.3 & 59.76 & 25.9 & 50.81 \\
\hline$A+B+C+D$ & 5.1 & 0.15 & 22.3 & 47.61 & 25.2 & 41.13 \\
\hline Overall mean \pm SE & $5.1 \pm 0.29$ & 1.09 & $20.3 \pm 1.5$ & 95.31 & $24.8 \pm 1.57$ & 49.51 \\
\hline
\end{tabular}

H: leaf-harvested plants, NH: non-leaf-harvested plants.

of SYSTAT [22]. The relative mixture effect on cowpea leaf $\mathrm{DM}$ and grain yields was calculated as follows:

Mixture effect (\%)

$$
=\frac{\text { Mixture yield }- \text { Pure line component average }}{\text { Pure line component average }} \times 100 \text {. }
$$

Statistical differences in mean yields for every mixture were calculated from a matrix using a contrast test of SYSTAT procedure at 5\% level. The same basic model used for analysis of genotype-by-environment interaction was applied in this study to analyse for stability. Regression analysis was used to determine whether each genotype exhibits a characteristic linear response to environmental change. The observed performance $\left(Y_{i j}\right)$ of the $i$ th genotype $(i=1, \ldots, g)$ in the $j$ th environment $(j=1, \ldots, e)$ was expressed as

$$
Y_{i j}=\mu+g_{i}+e_{j}+g e_{i j}+\varepsilon_{i j},
$$

where $\mu$ is the grand mean of overall genotypes and environments, $g_{i}$ is the additive contribution of the $i$ th genotype, $e_{j}$ is the additive environment contribution of the $j$ th environment, $g e_{i j}$ is the genotype-environment interaction of the $i$ th genotype in the $j$ th environment, and $\varepsilon_{i j}$ is the experimental error of $i$ th genotype in the $j$ th environment [23]. To be able to measure the contribution of the ith genotype to the genotype-by-environment interaction, Hill et al. [23] propose a parameter ecovalence $(W)$ expressed as

$$
W_{i}=\sum_{j}\left(Y_{i j}-Y_{i .}-Y_{. j}+Y_{. .}\right)^{2}
$$

where $Y_{\text {.. }}$ is the overall mean, $Y_{i}$ the mean of genotype $i$, and $Y_{. j}$ the mean of environment $j$. PLABSTAT [24] was used to generate ecovalence values as a measure of relative stability, with low ecovalence values indicating higher stability. A model that analyzes a series of experiments over places in a complete randomized block design with one factor was used in PLABSTAT, when analyzing for ecovalence values:

$$
\text { Model } P+R: P+T+T P+R T P \text {, }
$$

where $T$ is treatments, $R$ replications, and $P$ places.

\section{Results}

3.1. Effect of Cowpea Mixing on Leaf and Grain Yields. Variety $E$ had the lowest overall mean leaf DM yield of $2.4 \mathrm{~g} / \mathrm{m}^{2}$, while the highest overall mean leaf DM yield of $6.7 \mathrm{~g} / \mathrm{m}^{2}$ was realized from both variety $\mathrm{C}$ and mixture $\mathrm{B}+\mathrm{C}$ (Table 3 ). Mixing of cowpea varieties had both positive and negative 


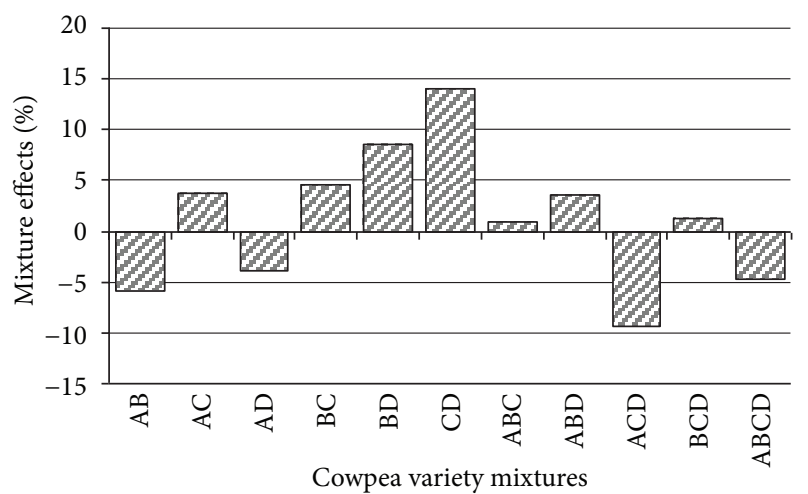

FIGURE 1: Effect of mixing cowpea varieties on leaf DM yield for the study conducted during 2008 at three locations of NaSARRI, Serere, Kikota, and Kogili villages in eastern Uganda. None of the mixture effects is significantly different at $P \leq 0.05$.

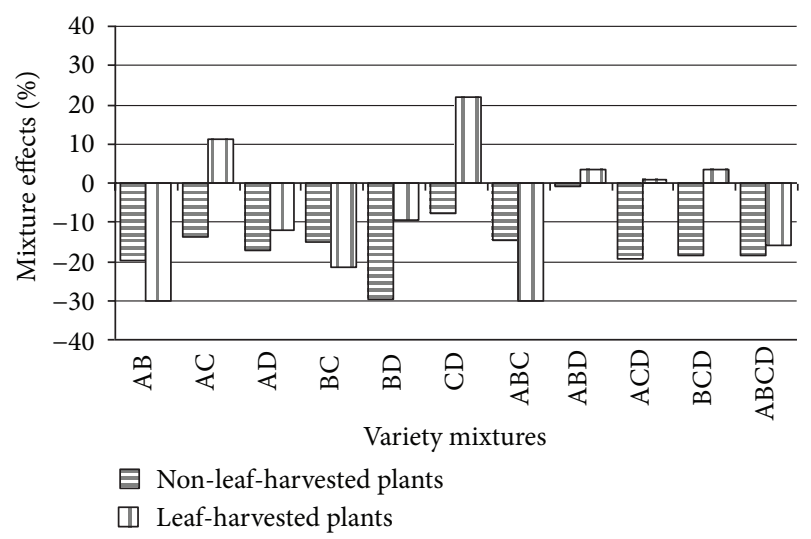

FIGURE 2: Mean effect of mixing cowpea varieties on grain yield from both leaf-harvested and non-leaf-harvested plants grown during 2008 at NaSARRI, Serere, Kikota, and Kogili villages in eastern Uganda. Values are not significantly different at $P \leq 0.05$.

effects on leaf DM yield. Relative mixture effects ranged from $-9.3 \%$ in $\mathrm{A}+\mathrm{C}+\mathrm{D}$ to $14.0 \%$ in C + D (Figure 1). On average, positive effects were observed for seven out of the eleven mixtures, but none of the mixture effects was significantly different at $P<0.05$.

The highest grain yield of $36.7 \mathrm{~g} / \mathrm{m}^{2}$ among the varieties was achieved from the non-leaf-harvested plants of variety $\mathrm{B}$, while the lowest grain yield of $12.1 \mathrm{~g} / \mathrm{m}^{2}$ came from the leaf-harvested plants of variety D. Grain yield of the non-leafharvested plants on average was higher than that of the leafharvested plants. Positive mixture effects on grain yield were seen only among the leaf-harvested plants. Mixture $\mathrm{C}+\mathrm{D}$ had the highest positive mixture effects of $21.9 \%$, while mixture $\mathrm{A}+\mathrm{B}$ had the most negative effects of $30.2 \%$ (Figure 2). None of the mixture effects on grain yield were significant at $P<0.05$.

3.2. Stability of Cowpea Leaf DM and Grain Yield. Variety mixture B + D had the lowest ecovalence value of 0.06 and, therefore, the most stable leaf yields, while variety $\mathrm{D}$ had the highest ecovalence value of 5.03, making it the most unstable variety for leaf yield across the three field sites (Table 3). Although the ecovalence value did not decrease with increasing number of component varieties in a mixture, on average, it was lower in mixtures than in individual varieties. Landraces had lower leaf yields but their ecovalence values were not always lower than those of the individual component varieties

Grain yields of variety A were the most unstable $\left(W_{i}=\right.$ 894.84), while those of mixture $B+D$ were the most stable $\left(W_{i}=4.45\right)$ among the leaf-harvested plants. The tendency was, however, different among non-leaf-harvested plants, where mixture $\mathrm{A}+\mathrm{B}$ was the most stable $\left(W_{i}=7.18\right)$ and mixture $\mathrm{B}+\mathrm{C}+\mathrm{D}$ was least stable $\left(W_{i}=125.22\right)$ for their grain yield across the three environments. No obvious relationship could be detected between ecovalence values and the number of components in a mixture for grain yield. Ecovalence values were also generally lower for the non-leaf-harvested plants than for leaf-harvested plants.

\section{Discussion}

Similar to this study, Kabululu et al. [25] and Erskine [14] observed both positive and negative effects of mixtures on cowpea grain yield. Some of the positive leaf and grain yields observed may be due to the more efficient use of space and resources for increased leaf size or pod number, which a neighbouring plant was not able to use. A phenomenon known as compensation effect was found among wheat variety mixtures [9]. For optimal leaf DM and grain yields in Uganda, mixtures of $\mathrm{B}+\mathrm{C}$ and mixture $\mathrm{C}+\mathrm{D}$, respectively, are recommended. The inconsistent performance of variety mixtures relative to the mean of individual varieties observed in this study has also been reported for oat [11, 26], barley [27], common bean [20], groundnut Arachis hypogaea L., sorghum, soya bean Glycine max (L.) Merr., maize, rye Secale cereal L., wheat, rice, cowpea, lima bean Phaseolus lunatus L., cotton Gossypium hirsutum L., and rapeseed Brassica napus L. [10]. As Bowden et al. [9] point out, stress happening late in the season or damage that affects grain yield without influencing plant size may hardly be compensated for by mixtures owing to the short time period of growth until the final harvest. Compensation for pest damage caused to susceptible cowpea plants by variety mixtures was less likely in this study given the fact that none of the individual varieties is known to have been bred for resistance to pests like aphids Aphis craccivora Koch, flower thrips Megalurothrips sjostedti Trybom, legume pod borers Maruca vitrata Fab. Syn. Maruca testulalis Geyer, and pod sucking bugs or diseases like scab, false rust, anthracnose, powdery mildew, and viral diseases that were encountered at some of the trial sites. However, Wolfe [8] points out that pest control using variety mixtures remains a challenge since some pests are able to search and locate the susceptible plants among a mixture of varieties unlike pathogenic spores whose spread can be obstructed by resistant plants. Choosing appropriate high-yielding varieties for use in mixture combinations was recommended as key to getting repeatable higher yields when 
working with variety mixtures [10,11]. When the competition between varieties for resources like light, soil nutrients, or soil water is greater than that within varieties, then negative yield differences are possible for variety mixtures $[10,11]$. This was probably the case in this study since three of the four varieties used in mixtures had an erect growth habit and nearly the same maturity period implying that they required the same space and nutrients at the same time, hence, the competition. Since neither leaf nor grain yield consistently increased with increasing number of component varieties in a mixture in this study, this may point to the fact that increased biodiversity alone may not always confer a yield advantage. Some individual cowpea varieties ( $\mathrm{C}$ and $\mathrm{B}$ ) in this study yielded better than some mixtures. In early maturing oat variety mixtures, Helland and Holland [11], as well, saw that some 2-way or 3-way mixtures did not always yield better than individual components. They also noted that the highest yielding mixture always contained the best-yielding component variety.

Leaf and grain yield stability across the three trial sites was the lowest for the individual cowpea varieties, and this is in line with what was observed for the same varieties in Dodoma, Tanzania [25]. The results of increased stability with increasing number of components in a mixture obtained in this study concur with those observed for winter wheat variety mixtures [13], hard red winter wheat [9], and early maturing oat varieties [11]. Like it was the case in this study, not all mixtures were more stable than individual cowpea varieties. For example, leaf yields of variety $C$ were more stable than those of mixtures $B+C, C+D, B+C+D$, and $A+D$. Also grain yields of leaf-harvested plants of variety $C$ were more stable than those of most of the variety mixtures except $\mathrm{A}+\mathrm{C}, \mathrm{B}+\mathrm{D}, \mathrm{A}+\mathrm{B}+\mathrm{C}+\mathrm{D}$, and $\mathrm{B}+\mathrm{C}$, indicating that increased diversity per se may not induce yield stability. Stability of mixtures may be due to the positive effects of compensation, like production of more pods or heavier grains by a vigorous plant neighbouring a nonvigorous plant or reduced interaction with the environment [8-10]. Among nine cowpea breeding lines grown in 13 environments in Nigeria under different management regimes, Blade et al. [15] noted that the stability of a given line was influenced more by the predictable effects of the treatments like cropping system and insecticide application than by the unpredictable variation among the environments.

Grain yield of cowpea variety mixtures was less affected by leaf-harvesting than that of single varieties. Nevertheless, the positive and negative mixture effects were neither significant for leaf nor for grain yields.

The vigorous growth of maize in this relay 1:1 cowpea/maize intercropping system reduced the amount of light reaching cowpea, making it impossible to achieve the full yield potential of cowpea. The density of maize, therefore, needs to be reduced in future studies and preferably a $1: 4$ maize/cowpea intercropping system should be used with both crops being planted at the same time. The performance of cowpea variety mixtures in sole crops needs to be studied as well. Due to the low fertility of the ferrisols and ferralitic soils in this region, use of nitrogen and phosphate fertilizers to enhance yields is highly recommendable.
There remains a challenge for cowpea breeders of identifying varieties that can give relatively high leaf and grain yields in traditional maize intercropping systems while maintaining the traits preferred by farmers and consumers.

\section{Conflict of Interests}

The authors declare that there is no conflict of interests regarding the publication of this paper.

\section{Acknowledgments}

This work was carried out within the project "Promotion of Neglected Indigenous Leafy and Legume Vegetable Crops for Nutritional Health in Eastern and Southern Africa" funded by the German Federal Ministry for Economic Cooperation and Development (BMZ, Project no. 2002.7860.6001.00). This study was supported by the GeorgAugust-Universität, Göttingen, Germany; NaSARRI, Serere, Uganda, and AVRDC-RCA, Arusha, Tanzania.

\section{References}

[1] H. C. Bittenbender, R. P. Barrett, and B. M. Indire-Lavusa, Beans and Cowpeas as Leaf Vegetables and Grain Legumes, vol. 1 of Occassional Monograph, Bean/Cowpea C.R.S.P., Michigan State University, East Lansing, MI, USA, 1984.

[2] E. B. Rubaihayo, "Conservation and use of traditional vegetables in Uganda," in Traditional African Vegetables. Promoting the Conservation and Use of Underutilized and Neglected Crops, Proceedings of the IPGRI International Workshop on Genetic Resources of Traditional Vegetables in Africa: Conservation and UseAugust 1995, ICRAF-HQ, Nairobi, Kenya, L. Guarino, Ed., pp. 109-114, Institute of Plant Genetics and Crop Plant Research, Gatersleben/ International Plant Genetic Resources Institute, Rome, Italy, 1997.

[3] A. G. Sabiti, E. N. B. Nsubuga, E. Adipala, and D. S. Ngambeki, "Socioeconomic aspects of cowpea production in Uganda: a rapid rural appraisal," Uganda Journal of Agricultural Science, vol. 2, pp. 29-35, 1994.

[4] P. Isubikalu, J. M. Erbaugh, A. R. Semana, and E. Adipala, "Influence of farmer production goals on cowpea pest management in Eastern Uganda: implications for developing IPM programmes," African Crop Science Journal, vol. 7, no. 4, pp. 539-548, 1999.

[5] E. Adipala, P. Nampala, J. Karungi, and P. Isubikalu, "A review on options for management of cowpea pests: experiences from Uganda," Integrated Pest Management Reviews, vol. 5, no. 3, pp. 185-196, 2000.

[6] J. Karungi, E. Adipala, S. Kyamanywa, M. W. Ogenga-Latigo, N. Oyobo, and L. E. N. Jackai, "Pest management in cowpea. Part 2. Integrating planting time, plant density and insecticide application for management of cowpea field insect pests in eastern Uganda," Crop Protection, vol. 19, no. 4, pp. 237-245, 2000.

[7] E. Adipala, "Dissemination and adoption of IPM menus for cowpea and groundnut production in Eastern Uganda: scaling up to achieve impact," Final Technical Report, Makerere University, Kampala, Uganda, 2003.

[8] M. S. Wolfe, "The current status and prospects of multiline cultivars and variety mixtures for disease resistance," Annual Review Phytopathology, vol. 23, pp. 251-273, 1985. 
[9] R. Bowden, J. Shroyer, K. Roozeboom et al., Performance of Wheat Variety Blends in Kansas. Keeping Up With Research 128, Kansas State University Agricultural Experiment Station and Cooperative Extension Service, Manhattan, Kan, USA, 2001, http://www.oznet.ksu.edu/library/crpsl2/SRL128.pdf.

[10] J. M. Lenné and J. B. Smithson, "Varietal mixtures: a viable strategy for sustainable productivity in subsistence agriculture?" Aspects of Applied Biology, vol. 39, pp. 163-172, 1994.

[11] S. J. Helland and J. B. Holland, "Blend response and stability and cultivar blending ability in oat," Crop Science, vol. 41, no. 6, pp. 1689-1696, 2001.

[12] A. C. Newton, R. P. Ellis, C. A. Hackett, and D. C. Guy, "The effect of component number on Rhynchosporium secalis infection and yield in mixtures of winter barley cultivars," Plant Pathology, vol. 45, no. 6, pp. 930-938, 1997.

[13] C. Cowger and R. Weisz, "Winter wheat blends (mixtures) produce a yield advantage in North Carolina," Agronomy Journal, vol. 100, no. 1, pp. 169-177, 2008.

[14] W. Erskine, "Adaptation and competition in mixtures of cowpea (Vigna unguiculata (L.) Walp.)," Euphytica, vol. 26, no. 1, pp. 193-202, 1977.

[15] S. F. Blade, D. E. Mather, B. B. Singh, and D. L. Smith, "Evaluation of yield stability of cowpea under sole and intercrop management in Nigeria," Euphytica, vol. 61, no. 3, pp. 193-201, 1991.

[16] M. R. Finckh, E. S. Gacek, H. Goyeau et al., "Cereal variety and species mixtures in practice, with emphasis on disease resistance," Agronomie, vol. 20, no. 7, pp. 813-837, 2000.

[17] K. S. Gill, G. S. Nanda, and G. Singh, "Stability analysis over seasons and locations of multilines of wheat (Triticum aestivum L.)," Euphytica, vol. 33, no. 2, pp. 489-495, 1984.

[18] A. C. Newton and J. S. Swanston, "Cereal variety mixtures reducing inputs and improving yield and quality: why isn't everybody growing them?” Annual Report 1998/99, Scottish Crop Research Institute, 1998.

[19] USDA/National Agricultural Statistics Service, Washington Annual Agriculture Bulletin, 2008, http://www.nass.usda.gov/ Statistics_by_State/Washington/Publications/Annual_Statistical_Bulletin/annual2008.pdf.

[20] C. S. Wortmann, H. E. Gridley, and S. M. Musaana, "Seed yield and stability of bean multiline," Field Crops Research, vol. 46, no. 1-3, pp. 153-159, 1996.

[21] S. K. Selvaradjou, L. Montanarella, O. Spaargaren, and D. Dent, European Digital Archive of Soil Maps (EuDASM)Soil Maps of Africa EUR 21657 EN, 2005, http://eusoils.jrc.ec .europa.eu/esdb_archive/EuDASM/Africa/lists/cug.htm.

[22] SYSTAT, SYSTAT 5.0 for Windows, SYSTAT, Chicago, Ill, USA, 1994.

[23] J. Hill, H. C. Becker, and P. M. A. Tigerstedt, Quantitative and Ecological Aspects of Plant Breeding, vol. 4 of Plant Breeding, Chapman and Hall, London, UK, 1998.

[24] H. F. Utz, PLABSTAT-A Computer Program For the Statistical Analysis of Plant Breeding Experiments, Institute of Plant Breeding, Seed Science, and Population Genetics, University of Hohenheim, Stuttgart, Germany, 1997, https://www.unihohenheim.de/plantbreeding/software/.

[25] S. M. Kabululu, C. Ojiewo, M. Oluoch, and B. L. Maass, "Cowpea cultivar mixtures for stable and optimal leaf and seed yields in a maize intercropping system," International Journal of Vegetable Science, vol. 20, no. 3, 2013.
[26] R. Shorter and K. J. Frey, "Relative yields of mixtures and monocultures of oat genotypes," Crop Science, vol. 19, pp. 548$553,1979$.

[27] C. C. Mundt, P. M. Hayes, and C. C. Schon, "Influence of barley variety mixtures on severity of scald and net blotch and on yield," Plant Pathology, vol. 43, no. 2, pp. 356-361, 1994. 


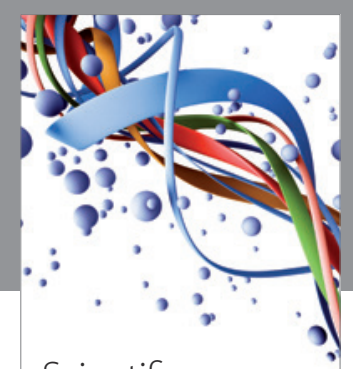

Scientifica
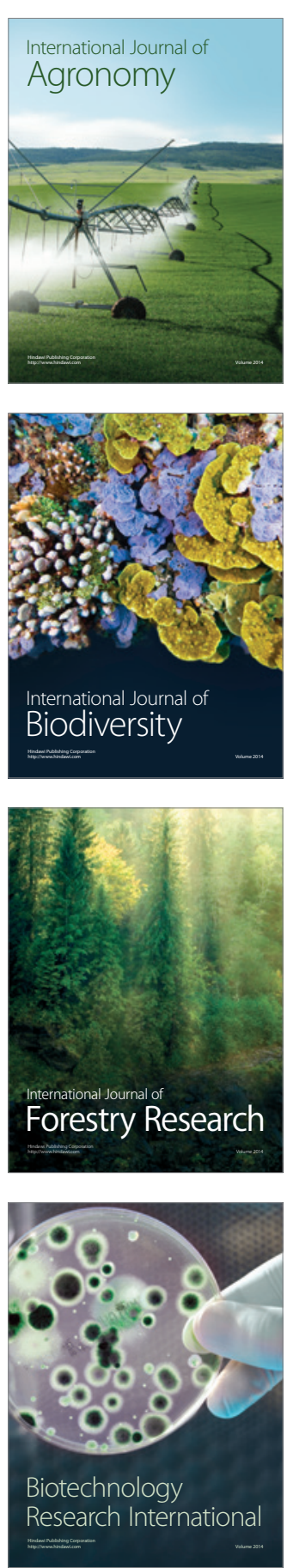
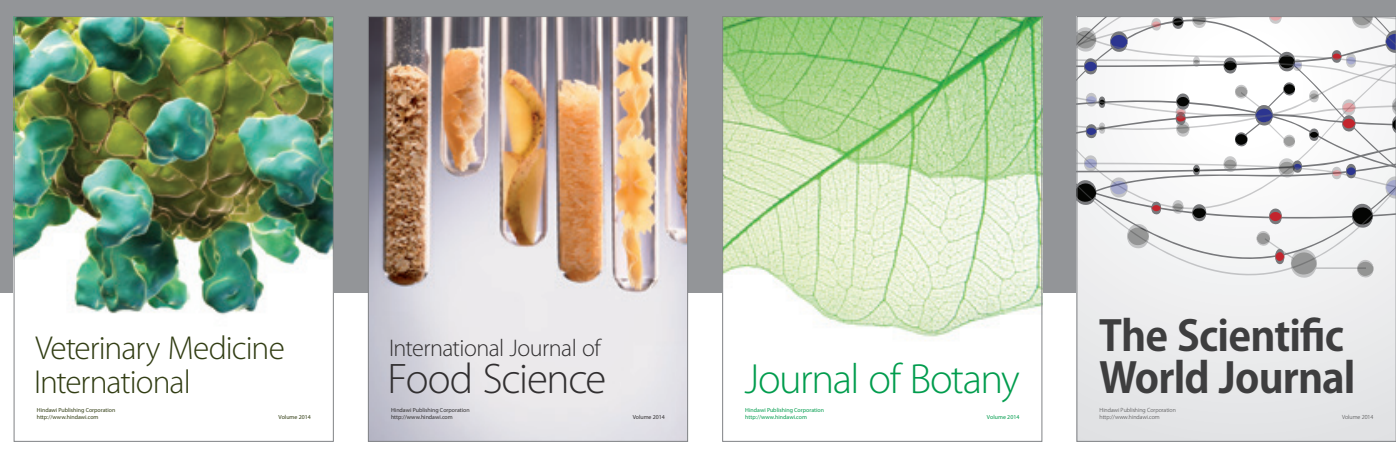

The Scientific World Journal
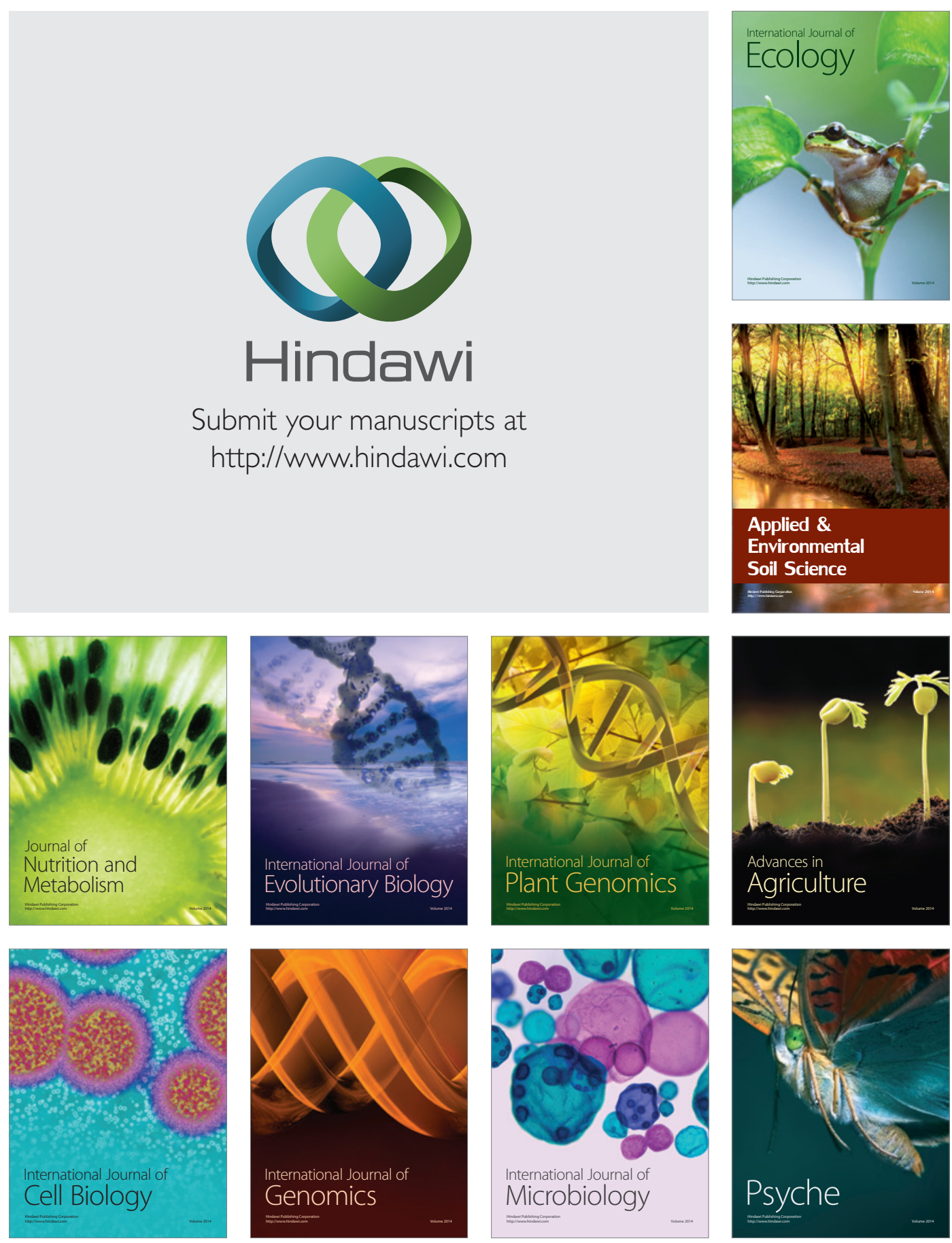